\title{
HUBUNGAN MOTIVASI MENJADI PERAWAT DENGAN PRESTASI BELAJAR MATA KULIAH KDM DAN KDK PADA MAHASISWA DIII KEPERAWATAN BAITUL HIKMAH BANDAR LAMPUNG
}

\author{
Sri Suharti, Nurhayati \\ Akademi Keperawatan Baitul Hikmah Bandar Lampung \\ Email : srisuharti1977@gmail.com
}

\begin{abstract}
ABSTRAK
Motivasi adalah semua hal yang dibutuhkan baik verbal, fisik, atau psikologis yang mendorong seseorang untuk melakukan sesuatu demi menyalurkan dan mempertahankan kearah sesuatu yang ingin dicapai. Pentingnya motivasi dalam proses pendidikan maka diperlukan pemahaman secar tuntas dan mendalam agar pengelolaan pendidikan di Akademi Keperawatan Baitul Hikmah Bandar Lampung akan lebih baik lagi. Tujuan penelitian ini adalah diketahuinya hubungan motivasi menjadi perawat dengan prestasi belajar mata kuliah Kebutuhan dasar manusia (KDM) dan Konsep Dasar Keperawatan (KDK) pada mahasiswa DIII keperawatan Akper Baitul Hikmah Bandar Lampung tahun 2014. Jenis penelitian yang digunakan yaitu deskriptif korelatif dengan pendekatan cross sectional. Populasi dalam penelitian ini adalah mahasiswa tingkat I, II dan III Akper Baitul Hikmah Bandar Lampung yang berjumlah 316 orang, dengan sampel 176 responden. Analisa bivariat yang digunakan adalah Chi Squere $\left(\mathrm{X}^{2}\right)$.Hasil uji statistik didapatkan tidak ada hubungan motivasi menjadi perawat terhadap prestasi belajar mata kuliah KDM ( $p$-value $=1,000)$ dan $\mathrm{KDK}(p$ - value $=0,845$ ) pada mahasiswa DIII keperawatan Akper Baitul Hikmah Bandar Lampung tahun 2014. Saran, diharapkan bagi institusi pendidikan untuk dapat memberikan pelayanan pendidikan keperawatan melalui peningkatan kualitas pendidikan mahasiswa di Akper Baitul Hikmah Bandar Lampung, dengan cara memberikan motivasi dan arahan sehingga prestasi belajar mahasiswa semakin baik.Serta pembimbing akademik untuk dapat meningkatkan pengawasan, bimbingan dan konseling pada mahasiswa.
\end{abstract}

Kata kunci : Motivasi menjadi perawat, Prestasi belajar mata kuliah KDM dan KDK

\begin{abstract}
Motivation is anything required including verbally, physically, and psychologically which encourage someone to do something for expressing and defending into a specific goal. The motivation in education process is important so that deep and complete understanding is required so that Baitul Hikmah Academy of nursing in Bandar Lampung will be better. The objective of this research was to find out the correlation between motivation of becoming nurse and learning achievement of KDM and KDK subjects of students in Baitul Hikmah DIII of Nursing Science in Bandar Lampung in 2014.

This was a descriptive correlation research with cross sectional approach. Population was 316 students of first, second, and third year in Baitul Hikmah Academy of Nursing in Bandar Lampung. Samples were 176 respondents. Data were analyzed with bivariate analysis by using chi square test.

The statistic test results showed that there was no correlation between motivation of becoming nurse and learning achievement of KDM (p-value = 1.000) and KDK (p-value = 0.845) subjects of students in Baitul Hikmah DIII of Nursing Science in Bandar Lampung in 2014. The researcher expects education institution to be able to provide nursing education by improving education quality in Baitul Hikam Academy of Nursing in Bandar Lampung by giving motivation and direction so that students' achievements will be improved. Academic consultants should enhance their monitoring and counselling for students.
\end{abstract}

Keywords: Motivation of becoming nurse, KDM and KDK learning Achievement 


\section{PENDAHULUAN}

Meskipun sekarang ini terdapat banyak perguruan tinggi negri maupun swasta, baik di tingkat kabupaten maupun propinsi, namun setelah menyelesaikan pendidikan SMA dan SMK, seringkali siswa dihadapkan pada pilihan yang sulit untuk menentukan jalur pendidikan mana yang harus dipilih. Namun dengan cita-cita saja belum menjamin untuk meneruskan pendidikan keperguruan tinggi, akan tetapi harus memiliki kemampuan intelektual yang memadai dan didukung oleh kemampuan finansial yang memadai pula.

\section{Bagi lulusan SMA yang mempunyai} keinginan atau dorongan untuk secepatnya mendapatkan pekerjaan maka pilihan yang tepat adalah melanjutkan pendidikan ke jenjang pendidikan tinggi diploma DIII sesuai dengan bakat, keinginan diri dan kemampuannya. Salah satu pendidikan jalur professional dibidang kesehatan adalah pendidikan program Diploma DIII yang pada era 1980-2000 peminatnya cukup besar, tetapi pada akhir-akhir ini keinginan untuk masuk pendidikan Diploma DIII keperawatan dari tahun ke tahun cendrung tidak stabil. Pada Akademi Keperawatan Baitul Hikmah didapatkan jumlah mahasiswa yang masuk dari hasil sipensimaru tahun ajaran 2011/2012 sebanyak 115 mahasiswa, tahun 2012/2013 sebanyak 92, dan tahun 2013/2014 sebanyak 145 orang. Melihat data tersebut ternyata terjadi ketidak stabilan peminat calon mahasiswa.Ketidakstabilan jumlah mahasiswa tersebut dapat dipengaruhi oleh beberapa faktor salah satu diantaranya adalah, motivasi untuk memilih pendidikan diploma DIII keperawatan.

Mc. Donal mengatakan bahwa "motivation is a energy change whitin the person characterized by affective arousal and anticipatory goal reactions" maksudnya mengatakan bahwa motivasi adalah suatu perubahan energi di dalam pribadi seseorang yang ditandai dengan timbulnya afektif (perasaan) dan reaksi untuk mencapai tujuan menurut Oemar Hamalik dalam Syaiful Bahri (2008). Fenomena yang terjadi saat ini kebanyakan mereka yang masuk DIII keperawatan umumnya sangat bervariasi yaitu karena dipaksa orang tua, ikut-ikutan teman daripada tidak sekolah, tidak diterima perguruan tinggi negri, ingin secepatnya mendapatkan pekerjaan dan adapula yang merupakan cita-cita sejak kecil. Hal ini berdasarkan dari hasil wawancara yang dilakukan terhadap 20 mahasiswa di Akper Baitul Hikmah, 12 mahasiwa mengatakan karena keinginan orang tua, 5 karena ikutikutan teman dan 3 oang lainnya karena citacitanya dari kecil.

Dalam rangka meningkatkan mutu pendidikan keperawatan, institusi Diploma DIII keperawatan mengembangkan diri secara terus-menerus untuk meningkatkan kemampuan professional di bidang keperawatan. Akademi keperawatan Baitul 
Hikmah merupakan institusi pendidikan formal yang mendidik peserta didik agar menjadi perawat muslim professional yang unggul dibidangnya. Untuk mengetahui keberhasilan Akademi Keperawatan Baitul Hikmah sebagai intitusi pendidikan professional maka diantaranya perlu dilakukan penilaian prestasi belajar selama menempuh masa pendidikan.

Asmara (2009) mengatakan perstasi belajar merupakan hasil yang dicapai seseorang dalam penguasaan pengetahuan dan keterampilan yang dikembangkan dalam pelajaran lazimnya ditujukkan dengan tes angka nilai yang diberikan oleh gurunya.Dalam perguruan tinggi prestasi belajar mahasiswa dapat dilihat dari hasil KHS.

Muhibinsyah (2009) mengemukakan pendapatnya bahwa tidak ada seorangpun mahasiswa yang tidak menginginkan suatu prestasi belajar yang baik.Namun untuk memperoleh semua itu tidaklah mudah karena mengingat adanya perbedaan setiap individu baik motivasinya, karakternya, cita-citanya dan lain-lain yang dimiliki oleh setiap mahasiswa. Dengan perbedaan yang demikian akan menyebabkan tercapainya suatu prestasi belajar yang berbeda pula yaitu prestasinya ada yang tergolong tinggi,sedang dan rendah. Hal ini dapat terjadi karena banyaknya faktor di mana salah satu di antaranya adalah motivasi.
Berdasarkan penelitian Nabhani (2007) terdapat hubungan yang positiif dan signifikan antar minat dan motivasi dengan prestasi belajar pada mahasiswa AKPER Muhammadiyah Surakarta pada tingkat signifikan $0,05 \%$. Penelitian serupa juga dilakukan oleh Wicahyanti (2010) yang menunjukkan ada korelasi antara minat dan motivasi terhadap prestasi belajar mahasiswa ekonomi UIN Malang dengan tingkat kepercayaan $10 \%$.Sehinggga dapat disimpulkan motivasi merupakan salah satu faktor yang positif dan signifikan dapat mempengaruhi prestasi belajar.

Berdasarkan data yang diperoleh dari kartu hasil study (KHS) mahasiswa Akper Baitul Hikmah tahun ajaran 2011/2012 dari mahasiswa $60 \%$ dari 115 mahasiswa mendapatkan nilai C untuk mata kuliah KDM, 25\% dari 115 mahasiswa mendapat nilai $\mathrm{C}$ untuk mata kuliah $\mathrm{KDK}$, pada tahun ajaran 2012/2013 30\% dari 87 mahasiswa mendapat nilai $\mathrm{C}$ untuk mata kuliah KDM dan KDK. Mahasiswa yang droop out pada tahun ajaran 2011/2012 ada 7 mahasiswa, sedangkan pada tahun ajaran 2012/2013 ada 5 mahasiswa.

Berdasarkan latar belakang dan fenomena di atas penulis tertarik untuk melakukan penelitian tentang "Hubungan Motivasi Menjadi Perawat Dengan Prestasi Belajar Mata Kuliah KDM dan KDK pada mahasiswa DIII Keperawatan Akper Baitul Hikmah Bandar Lampung Tahun 2014". 
Kuesioner yang digunakan pada penelitian ini

\section{METODOLOGI}

Desain penelitian adalah rencana atau struktur penyelidikan yang disusun sedemikian rupa sehingga peneliti dapat memperoleh jawaban atas pertanyaan-pertanyaan penelitian atau hipotesa (Karlinger, 2010 ). Metode penelitian yang digunakan ini adalah metode penelitian survei, yang dititik beratkan pada penelitian korelasional dengan pendekatan crossectional, yakni mempelajari hubungan-hubungan variabel. Penelitian survei adalah penelitian yang mengambil sampel dari suatu populasi dan menggunakan kuesioner sebagai alat pengumpulan data yang pokok (Singarimbun dan Effendi, 2003.

Waktu penelitian ini dilaksanakan pada bulan Juni - Juli 2014, di Akademi Keperawatan Baitul Hikmah Bandar Lampung. Populasi dalam penelitian ini adalah Mahasiswa tingkat I,II,III DIII Akademi Keperawatan Baitul Hikmah Bandar Lampung tahun 2014 yang berjumlah 316 orang.

Sampel yang diambil berjumlah 176 orang mahasiswa sebagai responden. Alat pengumpulan data dalam penelitian ini menggunakn kuesioner.Kuesioner dikembangkan oleh peneliti sebelum digunakan untuk penelitian. Kuesioner akan diuji coba terlebih dahulu. merupakan modifikasi dari kategori skala Likert. Pada penelitian ini peneliti mengadaptasi pilihan diatas menjadi nilai 1 untuk sangat tidak setuju, 2 untuk tidak setuju, 3 untuk setuju dan 4 untuk sangat setuju.

\section{HASIL}

a. Hubungan motivasi menjadi perawat terhadap prestasi belajar mata kuliah KDM pada mahasiswa DIII keperawatan Akper Baitul Hikmah Bandar Lampung Tahun 2014

Hasil uji statistik dengan chi square diperoleh nilai $p$-value $=1,000$ maka dapat disimpulkan bahwa tidak ada hubungan yag signifikan antara motivasi menjadi perawat dengan prestasi belajar mata kuliah KDM pada mahasisswa DIII Akper Baitul Hikmah Bandar Lampung tahun 2014. Kemudian diperoleh pula nilai OR : 1.031, artinya mahasiswa yang motivasinya tinggi memiliki peluang 1,031 kali untuk memperoleh prestasi belajar yang baik, dibanding dengan mahasiswa yang motivasinya sedang. Hal ini bertentangan dengan hasil penelitian yang dilakukan oleh Wicahyanti (2010) yang menunjukkan ada korelasi antara minat dan motivasi terhadap prestasi belajar mahasiswa ekonomi UIN Malang dengan tingkat kepercayaan $10 \%$. Sehinggga dapat disimpulkan motivasi merupakan salah satu faktor yang positif dan signifikan dapat mempengaruhi prestasi belajar. 
Hasil penelitian ini menunjukkan bahwa motivasi menjadi perawat tidak ada hubungan dengan prestasi belajar mata kuliah KDM , karena sebagian responden yang memilki motivasi tinggi untuk menjadi perawat mempunyai prestasi belajar yang sedang pada mata kuliah KDM.

Menurut Teori Herzberg (teoriduafaktor) dalam Sudrajat (2008), mengatakan bahwa ada dua faktor dari motivasi, yaitu faktor motivasional dan faktor hygiene atau pemeliharaan.Yang dimaksud faktor motivasional adalah hal-hal yang mendorong berprestasi yang sifatnya intrinsik, yang berarti bersumber dari dalam diri seseorang. Sedangkan yang dimaksud dengan faktor hygene atau pemeliharaan adalah faktorfaktor yang sifatnya ekstrinsik yang berarti bersumber dari luar diri yang turut menentukan perilaku seseorang dalam kehidupannya. Dalam mencapai prestasi belajar yang baik bukan hanya sekedar motivasi yang dapat mempengaruhi, tetapi ada faktor-faktor lain bisa berasal dari dalam maupun dari luar subyek. Tetapi dalam proses interaksi belajar mengajar faktor yang berasal dari dalam dirilah yang paling berpengaruh. Seperti yang dikemukakan oleh Thomas F. Saton dalam Sardiman (2012), yang mengatakan ada 6 faktor psikologis yang dapat mempengaruhi prestasi belajar yaitu : motivasi, konsentrasi, reaksi, organisasi, pemahaman dan ulangan.

Berdasarkan uraian diatas, maka menurut peneliti motivasi menjadi perawat tidak berpengaruh terhadap baik atau tidaknya prestasi belajar yang didapatkan mahasiswa.

b. Hubungan motivasi menjadi perawat terhadap prestasi belajar mata kuliah $\mathrm{KDK}$ pada mahasiswa DIII keperawatan Akper Baitul Hikmah Bandar Lampung Tahun 2014

Hasil uji statistik dengan chi square diperoleh nilai $p$-value $=0,845$ maka dapat disimpulkan bahwa tidak ada hubungan yag signifikan antara motivasi menjadi perawat dengan prestasi belajar mata kuliah KDK pada mahasisswa DIII Akper Baitul Hikmah Bandar Lampung tahun 2014.

Kemudian diperoleh pula nilai OR : 0,483 , artinya mahasiswa yang motivasinya tinggi memiliki peluang 0,483 kali untuk memperoleh prestasi belajar yang baik, dibanding dengan mahasiswa yang motivasinya sedang.

Hal ini bertentangan dengan hasil penelitian yang dilakukan oleh Wicahyanti (2010) yang menunjukkan ada korelasi antara minat dan motivasi terhadap prestasi belajar mahasiswa ekonomi UIN Malang dengan tingkat kepercayaan $10 \%$. Sehinggga dapat disimpulkan motivasi merupakan salah satu faktor yang positif dan signifikan dapat mempengaruhi prestasi belajar.

Hasil penelitian ini menunjukkan bahwa motivasi menjadi perawat tidak ada hubungan dengan prestasi belajar mata kuliah KDM , karena sebagian responden yang memilki motivasi tinggi untuk menjadi perawat 
mempunyai prestasi belajar yang sedang pada mata kuliah KDM.

Menurut Teori Herzberg (teori dua faktor) dalam Sudrajat (2008), mengatakan bahwa ada dua faktor dari motivasi, yaitu faktor motivasional dan faktor hygiene atau pemeliharaan.Yang dimaksud faktor motivasional adalah hal-hal yang mendorong berprestasi yang sifatnya intrinsik, yang berarti bersumber dari dalam diri seseorang. Sedangkan yang dimaksud dengan faktor hygene atau pemeliharaan adalah faktorfaktor yang sifatnya ekstrinsik yang berarti bersumber dari luar diri yang turut menentukan perilaku seseorang dalam kehidupannya.

Dalam mencapai prestasi belajar yang baik bukan hanya sekedar motivasi yang dapat mempengaruhi, tetapi ada faktor-faktor lain bisa berasal dari dalam maupun dari luar subyek. Tetapi dalam proses interaksi belajar mengajar faktor yang berasal dari dalam dirilah yang paling berpengaruh. Seperti yang dikemukakan oleh Thomas F. Saton dalam Sardiman (2011), yang mengatakan ada 6 faktor psikologis yang dapat mempengaruhi prestasi belajar yaitu : motivasi, konsentrasi, reaksi, organisasi, pemahaman dan ulangan.

Berdasarkan uraian diatas, maka menurut peneliti motivasi menjadi perawat tidak berpengaruh terhadap baik atau tidaknya prestasi belajar yang didapatkan mahasiswa.

\section{PEMBAHASAN}

E-ISSN : No. 2615-8604

Sebagian besar responden mendapat nilai sedang (60-74) yaitu sebanyak 131 responden untuk mata kuliah KDM. Hasil penelitian ini menunjukkan bahwa responden memiliki prestasi belajar yang sedang untuk mata kuliah KDM.

Untuk mata kuliah KDK sebagian besar responden pun mendapatkan nilai sedang (6074) yaitu sebanyak 118 responden. Hasil penelitian ini menunjukkan bahwa responden memiliki prestasi belajar yang sedang untuk mata kuliah KDK.

Hal ini bertentangan dengan hasil penelitian yang dilakukan oleh Wicahyanti (2010) yang menunjukkan ada korelasi antara minat dan motivasi terhadap prestasi belajar mahasiswa ekonomi UIN Malang dengan tingkat kepercayaan $10 \%$. Sehinggga dapat disimpulkan motivasi merupakan salah satu faktor yang positif dan signifikan dapat mempengaruhi prestasi belajar.

Menurut Muhibinsyah (2009) bahwa tidak ada seorangpun mahasiswa yang tidak menginginkan suatu prestasi belajar yang baik. Namun untuk memperoleh semua itu

tidaklah mudah karena mengingat adanya perbedaan setiap individu baik motivasinya, karakternya, cita-citanya dan lain-lain yang dimiliki oleh setiap mahasiswa. Dengan 
perbedaan yang demikian akan menyebabkan tercapainya suatu prestasi belajar yang berbeda pula yaitu prestasinya ada yang tergolong tinggi, sedang dan rendah.

Dari uraian di atas dapat disimpulkan bahwa dengan hanya memiliki motivasi saja belum bisa memastikan seseorang untuk memiliki prestasi belajar yang baik. Karena untuk memperoleh suatu prestasi belajar yang baik bukan hanya motivasi yang diperlukan, minat pun bisa menjadi faktor yang mempengaruhi prestasi belajar.

Hasil penelitian didapatkan sebagian besar responden memilki motivasi yang tinggi untuk menjadi perawat yaitu sebanyak 172 responden. Hal ini bertentangan dengan penelitian Nabhani (2007) terdapat hubungan yang positif dan signifikan antar minat dan motivasi dengan prestasi belajar pada mahasiswa AKPER Muhammadiyah Surakarta pada tingkat signifikan $0,05 \%$. Hasil penelitian ini menunjukkan bahwa responden memiliki motivasi yang tinggi untuk menjadi perawat. Motivasi adalah karakteristik psikologi manusia yang memberikan kontribusi pada tingkat komitmen seseorang. Hal ini termasuk faktor-faktor yang menyebabkan,

menyalurkan, dan mempertahankan tingkah laku manusia dalam arah tekad tertentu menurut Stonner dan Freeman dalam Nursalam (2008). Motivasi menurut Ngalim
Purwanto dalam Nursalam (2008) adalah segala sesuatu yang mendorong seseorang untuk melakukan sesuatu. Motivasi adalah perasaan atau pikiran yang mendorong seseorang melakukan pekaryaan atau menjalankan kekuasaan terutama dalam berprilaku. Menurut Nancy Stevenson (2006) motivasi adalah semua hal verbal, fisik, atau psikologis yang membuat seseorang melakukan sesuatu sebagai respons.

Dari berbagai pendapat di atas dapat ditarik kesimpulan bahwa untuk menilai motivasi harus meliputi semua aspek baik fisik, verbal maupun psikologis.

\section{KESIMPULAN}

Berdasarkan hasil penelitian dan pembahasan, maka dapat diambil beberpa kesimpulan sebagai berikut :

a. Sebagian besar responden di Akper Baitul Hikmah Bandar Lampung memilki prestasi belajar sedang dengan rentang nilai 60-74 untuk mata kuliah KDM yaitu sebanyak 131 responden $(74,4 \%)$.

b. Sebagian besar responden di Akper Baitul Hikmah Bandar Lampung memilki prestasi belajar sedang dengan rentang nilai 60-74 untuk mata kuliah KDK yaitu sebanyak 118 responden (67,0\%).

c. Sebagian besar responden di Akper Baitul Hikmah Bandar Lampung memilki motivasi tinggi untuk menjadi perawat yaitu sebnyak 172 responden ( 97,7\%). 
d. Tidak ada hubungan motivasi menjadi perawat dengan prestasi belajar mata kuliah KDM ( p- value $=1,000)$ pada mahasiswa DIII Akper Baitul Hikmah tahun 2014.

e. Tidak ada hubungan motivasi menjadi perawat dengan prestasi belajar mata kuliah KDK ( p- value $=0,845)$ pada mahasiswa DIII Akper Baitul Hikmah tahun 2014

\section{KEPUSTAKAAN}

Asmara. (2009).Prestasi Belajar dan Hasil Belajar.Yoyakarta:Pustaka Belajar

Bahri, Sayful.(2011). Psikologi Belajar.Jakarta : Rineka Cipta.

Fred, N. Karlinger.(2010).Asas-asas Penelitian Behavioral. Yogyakarta : Gajah Mada University Press

Hidayat Alimul, Aziz.(2008).Metode Penelitian Keperawatan dan Teknik Analisis.Jakarta : Salemba Medika Muhibinsyah. (2009). Membangun Kompetensi Belajar.Jakarta : Dirjen Depdiknas

Nabhani.(2007). Hubungan minat dan motivasi dengan prestasi belajar pada mahasiswa AKPER Muhammadiyah Surakarta diperoleh dari http://nabhani.blogspot.com/2013/05/p roposal-skripsi-hubungan-antaraminat.html

Notoatmodjo, Sukidjo. (2012). Metode Penelitian Kesehatan.Jakarta :Rineka Cipta
Nursalam. (2008). Management Keperawatan. Aplikasi Dalam Praktik Keperawatan Profesional. Jakrta : Salemba Medika.

Polit dan Hungler.(2010).Nursing Research Principles and Methods Library of Congress Cataloging in apublications data

Sardiman. (2011). Interaksi dan Motivasi Belajar Mengajar Jakarta: PT. Raja Gafindo Persada

Singarimbun. (2003). Management Penelitian.Jakarta : Rineka Cipta

Stevenson, Nancy.(2006). Seni Motivasi. Yogyakarta: penerbit Andi.

Sudrajat, Akhmad.(2008). Pengertian Pendekatan, strategi, metode, teknik dan model pembelajaran.hhtp://akhmad sudrajat. wordpress.com /2008/09/2014 .pendekatan strategi metode teknik dan model pembelajaran/.di akses 7 April 2014.

Wicahyanti. (2010). Hubungan motivasi dan minat terhadap prestasi belajar mahasiswa ekonomi UIN Malang.

Diperoleh dari http://www.scribd.com/doc/28439967/ Pengaruh-Minat-Motivasi-BelajarTerhadap-Hasil-Belajar-Mahasiswa 